\title{
Potential of Typha latifolia L. for phytofiltration of iron-contaminated waters in laboratory-scale constructed microcosm conditions
}

\author{
Maibam Dhanaraj Meitei ${ }^{1}$ - Majeti Narasimha Vara Prasad ${ }^{2}$
}

Received: 7 July 2020 / Accepted: 10 December 2020 / Published online: 13 February 2021

(c) The Author(s) 2021

\begin{abstract}
The present study gave a preliminary report on the phytofiltration of iron-contaminated waters and aggravation of iron uptake by copper supplementation using Typha latifolia L. in constructed microcosms. During the experiment, Fe concentrations reduced up to $1.67 \pm 0.076 \mathrm{mg} \mathrm{L}^{-1}$ (94.43\% removal efficiency) and $0.087 \pm 0.013 \mathrm{mg} \mathrm{L}^{-1}$ ( $97.10 \%$ removal efficiency) by 14th day from the initial concentrations of $30 \mathrm{mg} \mathrm{L}^{-1}$ in the microcosm setups. Iron accumulation in the plant tissues was $2425.65 \pm 41.01 \mathrm{mg} \mathrm{kg}^{-1}$ (Fe with $\mathrm{Cu}$ ) compared with $1446.00 \pm 36.01 \mathrm{mg} \mathrm{kg}^{-1}$ (without $\mathrm{Cu}$ ), revealing that $\mathrm{Cu}$ addition in the microcosm setup magnifies Fe accumulation and removal. Thus, the results signify that constructed wetlands $(\mathrm{CW}) \mathrm{can}$ serve as the low-cost, ecofriendly alternative for wastewater treatment.
\end{abstract}

Keywords Phytoremediation · Wastewaters $\cdot$ Typha latifolia $\cdot$ Iron $\cdot$ Constructed wetlands

\section{Introduction}

Iron ( $\mathrm{Fe})$, when consumption exceeds $40 \mathrm{mg} \mathrm{kg}^{-1}$ body weight, can cause death (WHO 2011). The excess accumulation in the body may lead to hemochromatosis, hemorrhagic necrosis, sloughing mucosal areas in the stomach and tissue damage of organs by catalyzing $\mathrm{H}_{2} \mathrm{O}_{2}$ conversion to free radical ions that attacks cell membranes, proteins, breaks down DNA strands and activates oncogenes. Moreover, Fe toxicity causes diabetes mellitus, atherosclerosis and related cardiovascular diseases and hormonal abnormalities (Gurzau et al. 2003). Therefore, in order to safeguard the human health from Fe toxicity, Joint FAO/WHO Expert Committee on Food Additives (JECFA) has set a limit on the provisional maximum tolerable daily intake (PMTDI) of $0.8 \mathrm{mg} \mathrm{kg}^{-1}$ body weight, which is applicable to accumulation from numerous sources like coloring agents, food supplements and water (Joint FAO/WHO Expert Committee on Food Additives 1983).

Maibam Dhanaraj Meitei maibam.meitei@yahoo.in

1 Department of Forestry and Environmental Science, Manipur University, Canchipur 795003, India

2 Department of Plant Science, School of Life Sciences, University of Hyderabad, Hyderabad 500046, India
Various conventional treatment methods that include precipitation, reduction, artificial membranes and ion exchange techniques have been employed for the removal of heavy metals from domestic and industrial effluents (Meitei and Prasad 2014a). However, the techniques proved to be expensive and generate huge amount of waste that lead to disposal problems and showed ineffectiveness when the metals were present in the lowest concentrations. The reasons provide the need to look for different wastewater management techniques that are cost-effective and have low environmental impact. Phytoremediation approach that uses plants to reduce, remove and degrade pollutants is termed as a sustainable alternative for long-term decontamination of polluted environment (Prasad 2004) and an alternative method to solve the problem of Fe contamination in wastewater.

Although abundant in distribution, Fe bioavailability is low in the aquatic systems because of the extreme solubility of $\mathrm{Fe}^{3+}$ in alkaline calcareous soils, making the phytoextraction of Fe difficult from the natural environment. Thus, from the several phytoremediation practices, phytofiltration and rhizofiltration that involve the removal of pollutants by the roots with their transport into the aerial portions of the plant show a promising potential (Tel-Or and Forni 2011; Gomes et al. 2014). For the phytoremediation of domestic or industrial effluents contaminated with metals, plant species with high pollutant uptake capacity and enormous growth rate is a must. Recently, the use of $\mathrm{CW}$ which are engineered 
wastewater treatment systems that resembles the processes occurring in the natural treatment wetlands and used for the treatment of a wide variety of wastewaters, viz. industrial effluents, urban and agricultural, animal wastewaters, leachates, sludges, medical wastes and mine drainage, has been thoroughly studied (Afzal et al. 2019; Nguyen et al. 2019; Ashraf et al. 2020; Borralho et al. 2020; Khalid and Ganjo 2020; Kodituwakku and Yatawara 2020).

In the present preliminary laboratory-scale microcosm experiment, the potential of Typha latifolia L. to treat Fecontaminated wastewaters and its Fe uptake aggravation by $\mathrm{Cu}$ supplementation was studied to solve the problem of Fe pollution from the aquatic environment. Typha spp. are diversely distributed 11 species of emergent aquatic macrophytes belonging to Typhaceae family and grow naturally in floodplains, marshes, dams, drainage channels, wetlands and dump sites. The plant species showed high tolerance and high uptake capacity of numerous pollutants from various degraded environments making it a suitable candidate for use in constructed wetlands (Manios et al. 2003; Batool 2020; Hussien et al. 2020; Ventura et al. 2021).

\section{Materials and methods}

\section{Collection of T. Iatifolia}

Healthy young buds of $T$. latifolia were collected from Loktak, northeast India. The plants were transported to laboratory, repeatedly washed with tap water and rinsed with distilled water to remove unwanted materials. The plants were then cultivated with a density of 20 buds per square meter for $>30$ days, so the individuals might reach up to $30 \mathrm{~cm}$ in height (using normal tap water).

\section{Microcosm setups for Fe phytofiltration}

Laboratory-scale microcosms $(0.6 \mathrm{~m} \times 0.4 \mathrm{~m} \times 0.4 \mathrm{~m})$ were developed in the University of Hyderabad, School of Life Sciences green house facility with controlled environmental conditions of $18 \mathrm{~h}$-light length, temperature $25 \pm 2{ }^{\circ} \mathrm{C}$ and relative humidity $70 \%$, respectively (Fig. 1). The microcosms were filled to a depth of $30 \mathrm{~cm}$ with a mixture of sand and gravel $(1: 1, \mathrm{v} / \mathrm{v})$. In the microcosm one, $20 \mathrm{~L}$ of wastewater with $\mathrm{Fe}$ concentrations of $30 \mathrm{mg} \mathrm{L}^{-1}$ was transferred. Likewise, $20 \mathrm{~L}$ of wastewater with $\mathrm{Fe}$ and $\mathrm{Cu}$ concentrations of 30 and $15 \mathrm{mg} \mathrm{L}^{-1}$ was transferred in the microcosm two. In both the microcosms, three buds of $T$. latifolia $(15 \mathrm{~cm}$ long and same weight) each were cultivated and the experiment was carried out for a period of 14 days. The experiment was replicated for each treatment. During the experimentation, water samples were collected every day (1st to 14th day) from the outlets and preserved in decontaminated polyethylene bottles for analysis. Likewise, sediments were collected on the 1st, 7th and 14th day, respectively. Similarly, aerial vegetal plant parts of $T$. latifolia at about $5 \mathrm{~cm}$ above the water level were collected on the 1 st, 7 th and 14 th day.

\section{Photosynthetic pigment estimation}

For the estimation of pigments, vegetal parts were harvested on the 1st, 7th and 14th day, respectively. Estimation of pigment content was done following Arnon (1949) and Duxbury and Yenstch (1956). For the analysis, $0.1 \mathrm{~g}$ of plant part was ground in $5 \mathrm{~mL}$ chilled $80 \%$ acetone in dark. Then, the sample was centrifuged at $5000 \mathrm{~g}$ for $10 \mathrm{~min}$ at $4{ }^{\circ} \mathrm{C}$ and the absorbance of the supernatant recorded at 480 , 645 and $663 \mathrm{~nm}$ for the estimation of chlorophyll (Chl) and carotenoids.
Fig. 1 Schematic setup of constructed microcosm for $\mathrm{Fe}$ removal using T. latifolia $\mathrm{L}$

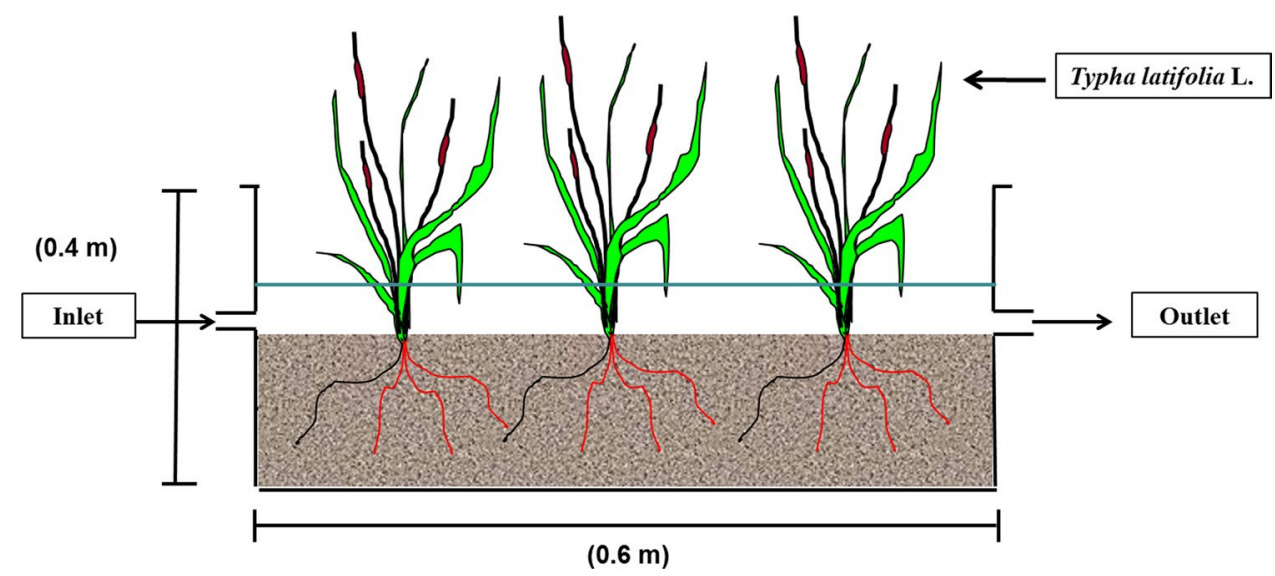




\section{Anthocyanin estimation}

Anthocyanin extraction was performed using $0.5 \mathrm{~g}$ vegetal parts (harvested on 1st, 7th and 14th day) in $10 \mathrm{~mL}$ of $n$-propanol/ $/ \mathrm{HCl} / \mathrm{H}_{2} \mathrm{O}(18: 1: 81, \mathrm{v} / \mathrm{v} / \mathrm{v})$ mixture. The samples were then heated in a boiling water bath for $30 \mathrm{~min}$ and further incubated in dark at $4{ }^{\circ} \mathrm{C}$ for $24 \mathrm{~h}$. The extracts were then filtered and the absorbance recorded at 535 and $650 \mathrm{~nm}$, with the anthocyanin content calculated and expressed according to Lange et al. (1971) and Bette and Kutschera (1996) as $\mathrm{A}_{535} \mathrm{~g}^{-1}$ fresh weight:

$\mathrm{A}_{535}=\mathrm{A}_{535}-0.22 \times \mathrm{A}_{650}$

\section{Iron and copper analysis of water, sediment and $T$. latifolia}

For analysis, water samples were filtered through $0.45-\mu \mathrm{m}$ Millipore membranes, acidified with conc. $\mathrm{HNO}_{3}$ to $\mathrm{pH}<2$ and stored in the dark at $4{ }^{\circ} \mathrm{C}$. Then, the acid digestion was carried out with conc. $\mathrm{HNO}_{3} / \mathrm{HClO}_{4}(3: 1, \mathrm{v} / \mathrm{v})$. Likewise, sediments were brought to laboratory, air-dried at room temperature for three days and sieved to remove any coarse debris. The samples were then ground using a mortar and sieved to get fine powders. The total metal content was determined by digesting the sediments with conc. $\mathrm{HNO}_{3} / \mathrm{HClO}_{4}$ $(3: 1, v / v)$. Similarly, the plant samples were thoroughly washed with tap water and rinsed with deionized water to remove any unwanted materials. The plant parts were then oven-dried $\left(70{ }^{\circ} \mathrm{C}\right)$ for $24 \mathrm{~h}$ to get a constant weight and then ground using a Clotech Powder Mill and later sieved to get fine powders. The samples were then acid-digested: $10 \mathrm{~mL}$ of $\mathrm{HNO}_{3} / \mathrm{HClO}_{4}, 3: 1$, v/v added to samples of $1.00 \mathrm{~g}$. After cooling at room temperature, the residue was diluted with double deionized water to $30 \mathrm{~mL}$. The heavy metal (Fe and $\mathrm{Cu}$ ) concentrations were determined using an Atomic Adsorption Spectrophotometer (GBC-932, Australia) for sediment, water and T. latifolia (Meitei and Prasad 2013). The quality control and method validation were done using standard reference materials and standards (Sisco Research Laboratories Pvt. Ltd., India) ran concurrently to calibrate the Atomic Adsorption Spectrophotometer.

\section{Translocation coefficient of Fe in T. latifolia}

The water-plant transfer coefficient (TC) was calculated as the relation between the metal ion concentrations in the plant parts and in the contaminated water as a proper way to express the relative metal absorption by $T$. latifolia.
$\mathrm{TC}=[\text { Metal ion }]_{\text {Plant parts }} /[\text { Metal ion }]_{\text {Water }}$

\section{Data analysis}

The results represent the mean \pm standard deviation values of experiments performed. Data were statistically evaluated using functions of Microsoft Excel 2010 (version Office Windows 7, Microsoft Corporation, USA).

\section{Results and discussion}

\section{Variation of $\mathrm{Fe}$ and $\mathrm{Cu}$ concentration in water}

The constructed microcosm's performances for $\mathrm{Fe}$ and $\mathrm{Cu}$ removal are shown in Table 1 . The $\mathrm{Fe}$ concentrations got reduced from the initial $30 \pm 0.0 \mathrm{mg} \mathrm{L}^{-1}$ to $1.67 \pm 0.076 \mathrm{~m} \mathrm{~L}^{-1}$ and $0.87 \pm 0.013 \mathrm{mg} \mathrm{L}^{-1}$ in the microcosms 1 and 2, respectively. The removal of Fe exceeded $94.43 \%$ in microcosm 1 and $97.10 \%$ in microcosm 2 by the 14th day (336-h) exposure period. Likewise, $\mathrm{Cu}$ concentration in microcosm 2 got reduced to $0.014 \pm 0.076 \mathrm{mg} \mathrm{L}^{-1}$ by 6 th day $(144 \mathrm{~h})$ from the initial concentration of $15 \pm 0.0 \mathrm{mg} \mathrm{L}^{-1}$. The metal removal was governed mainly through the process of phytofiltration and phytoextraction by $T$. latifolia, sedimentation and adsorption in the trickling filters in the microcosms. The iron-rich colloidal (precipitates) formation (milky white cloudy appearance) was observed on the surface of the wastewater in both the microcosms. Normally, Fe precipitation occurs subsequent to either atmospheric (abiotic) and bacterial mediated oxidation (Thiobacillus ferrooxidans, Sphaerotillus sp., Metallogenium sp., Crenothrix sp.) of Fe (II) to Fe (III) (Groudeva et al. 2001). Likewise, chemical precipitation of Fe added as hydrous oxides and hydroxides or oxyhydroxides after the diffusion of sufficient oxygen at the air-ware interface was observed. The initial $\mathrm{pH}$ was found between the ranges of 7.4 to 7.9 in both microcosms. It is important to mention that chemical precipitation of $\mathrm{Fe}$ occurs in the pH range of 3.5 to 9.0 (Metcalf et al. 2003) compared to bacterial mediated oxidation of Fe (II) and subsequent precipitation is not that likely to be observed at low $\mathrm{pH}$ conditions (Vyzamal 1995). It justifies that any direct involvement of microorganisms in the oxidation of $\mathrm{Fe}$ (II) and its subsequent precipitation was an insignificant process in the microcosms. In addition to the accumulation of Fe directly by the plant, the fallen litter also influences Fe retention in the microcosm. The decomposition of litter promotes the release of Fe from the sediment into the water medium, by transforming reducible $\mathrm{Fe}$ into exchangeable and oxidizable $\mathrm{Fe}$. A large portion of $\mathrm{Fe}$,

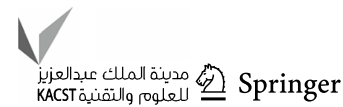


Table 1 Variation of $\mathrm{Fe}$ and $\mathrm{Cu}$ concentrations in water as a function of exposure period for the $\mathrm{Fe}$ and $\mathrm{Fe}-\mathrm{Cu}$ microcosms (mean \pm standard deviation)

\begin{tabular}{|c|c|c|c|c|c|c|}
\hline \multirow{2}{*}{$\begin{array}{l}\text { Exposure } \\
\text { period (h) }\end{array}$} & \multicolumn{2}{|c|}{ Contaminated water with $\mathrm{Fe}$} & \multicolumn{4}{|c|}{ Contaminated water with $\mathrm{Fe}-\mathrm{Cu}$} \\
\hline & $\begin{array}{l}\text { Concentration of } \\
\mathrm{Fe}\left(\mathrm{mg} \mathrm{L}^{-1}\right)\end{array}$ & Remaining $\mathrm{Fe}(\%)$ & $\begin{array}{l}\text { Concentration of } \\
\mathrm{Fe}\left(\mathrm{mg} \mathrm{L}^{-1}\right)\end{array}$ & Remaining $\mathrm{Fe}(\%)$ & $\begin{array}{l}\text { Concentration of } \\
\mathrm{Cu}\left(\mathrm{mg} \mathrm{L}^{-1}\right)\end{array}$ & Remaining $\mathrm{Cu}(\%)$ \\
\hline 0 & $30.00 \pm 0.00$ & $100.0 \pm 0.0$ & $30.00 \pm 0.00$ & $100 \pm 0.00$ & $15.00 \pm 0.00$ & $100.00 \pm 0.00$ \\
\hline 24 & $26.87 \pm 0.043$ & $89.57 \pm 1.3$ & $24.11 \pm 0.012$ & $80.37 \pm 2.1$ & $8.17 \pm 0.012$ & $54.45 \pm 1.8$ \\
\hline 48 & $21.09 \pm 0.021$ & $70.30 \pm 2.1$ & $19.98 \pm 0.048$ & $66.60 \pm 1.7$ & $3.76 \pm 0.062$ & $25.07 \pm 2.6$ \\
\hline 72 & $17.76 \pm 0.010$ & $59.17 \pm 3.4$ & $13.12 \pm 0.021$ & $43.73 \pm 2.0$ & $1.17 \pm 0.202$ & $7.80 \pm 1.5$ \\
\hline 96 & $11.56 \pm 0.097$ & $38.53 \pm 1.7$ & $9.36 \pm 0.013$ & $31.20 \pm 1.8$ & $1.02 \pm 0.069$ & $6.80 \pm 1.8$ \\
\hline 120 & $7.09 \pm 0.036$ & $23.63 \pm 2.8$ & $6.12 \pm 0.089$ & $20.40 \pm 1.6$ & $0.087 \pm 0.041$ & $0.58 \pm 2.5$ \\
\hline 144 & $5.43 \pm 0.061$ & $18.10 \pm 1.8$ & $4.78 \pm 0.038$ & $15.93 \pm 2.6$ & $0.014 \pm 0.076$ & $0.09 \pm 1.7$ \\
\hline 168 & $4.68 \pm 0.054$ & $15.60 \pm 1.9$ & $4.11 \pm 0.011$ & $13.70 \pm 2.3$ & - & - \\
\hline 192 & $4.23 \pm 0.082$ & $14.10 \pm 2.1$ & $3.89 \pm 0.054$ & $12.97 \pm 1.9$ & - & - \\
\hline 216 & $3.83 \pm 0.097$ & $12.77 \pm 2.6$ & $3.56 \pm 0.040$ & $11.86 \pm 3.5$ & - & - \\
\hline 240 & $3.11 \pm 0.011$ & $10.37 \pm 1.6$ & $2.87 \pm 0.022$ & $9.57 \pm 1.6$ & - & - \\
\hline 264 & $2.76 \pm 0.051$ & $9.20 \pm 0.9$ & $2.67 \pm 0.072$ & $8.90 \pm 1.2$ & - & - \\
\hline 288 & $2.25 \pm 0.046$ & $7.50 \pm 1.2$ & $1.23 \pm 0.078$ & $4.10 \pm 1.8$ & - & - \\
\hline 312 & $2.01 \pm 0.031$ & $6.70 \pm 2.3$ & $1.01 \pm 0.098$ & $3.37 \pm 2.7$ & - & - \\
\hline 336 & $1.67 \pm 0.076$ & $5.57 \pm 1.1$ & $0.87 \pm 0.013$ & $2.90 \pm 1.8$ & - & - \\
\hline
\end{tabular}
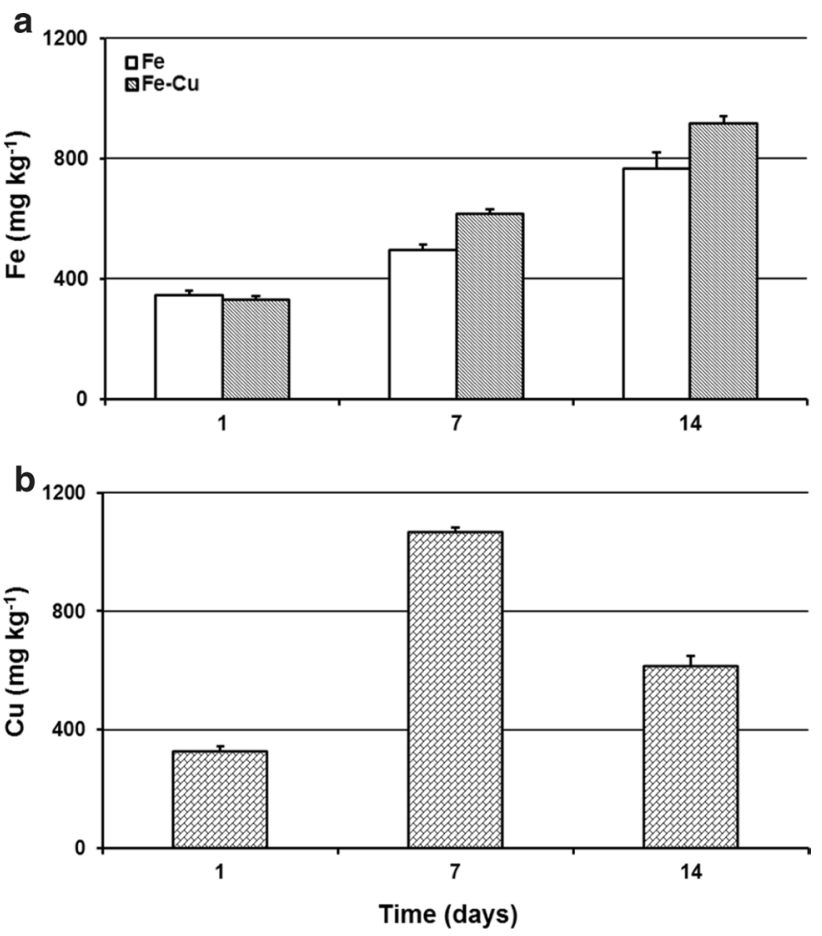

Fig. 2 Accumulation of (a) iron and (b) copper in the sediment of the two microcosms (Fe and $\mathrm{Fe}-\mathrm{Cu})$. Error bars represent $\mathrm{SD}(n=3)$

mostly the hydrated iron oxides, adsorbs onto the fallen litter due to their high binding affinities of Fe oxides (Wu et al. 2019). Thus, apart from the phytoextraction process, the plant detritus also plays an important part in $\mathrm{Fe}$ removal from the microcosm by acting as a sink.

\section{Variation of Fe and Cu concentration in sediment}

In the sediment, $\mathrm{Fe}$ and $\mathrm{Cu}$ concentrations got increased significantly. The results depicted a significant accumulation of both the metal ions in the microcosms during the experimentation period (Fig. 2a and b). The Fe concentration increased from $345.5 \pm 15.23 \mathrm{mg} \mathrm{kg}^{-1}$ to $765.75 \pm 53.82 \mathrm{mg} \mathrm{kg}^{-1}$ during 1 st and 14 th day of exposure in microcosm 1 compared to the increase from $329.25 \pm 14.23 \mathrm{mg} \mathrm{kg}^{-1}$ to $915.75 \pm 25.13 \mathrm{mg} \mathrm{kg}^{-1}$ during 1 st and 14th day exposure in microcosm 2, respectively. Similarly, $\mathrm{Cu}$ concentrations in the substrate of microcosm 2 increased from $329.5 \pm 15.23 \mathrm{mg} \mathrm{kg}^{-1}$ to $1065.45 \pm 17.81 \mathrm{mg} \mathrm{kg}^{-1}$ and $614.85 \pm 35.00 \mathrm{mg} \mathrm{kg}^{-1}$ during 1st, 7th and 14th exposure period, respectively. In the sediments, Fe accumulation is mainly found in the residual fraction with relatively low mobility and availability (Wu et al. 2019). The Fe concentrations in the substrate changed gradually with time, apart from slow flocculation rates and subsequent sedimentation of Fe-rich colloidals, and senescing plants too tend to produce Fe-rich organic detritus (underground parts). As a result, the organic detritus may complex with the settled precipitates of $\mathrm{Fe}_{2} \mathrm{O}_{3}$ and $\mathrm{Fe}(\mathrm{OH})_{3}$ through adsorptive mechanisms. Therefore, the detritus from the aboveground parts of $T$. latifolia may also serve as an additional adsorption site for Fe that remains 
in the wastewater (O'Sullivan et al. 2004). In addition, co-precipitation acts as an important adsorptive phenomenon in wetland sediments during the removal of heavy metals with the metals such as $\mathrm{Cu}$ co-precipitating with $\mathrm{Fe}$ oxides (Noller et al. 1994). In the setup, further $\mathrm{Cu}$ concentrations decrease may be attributed to the uptake of more $\mathrm{Cu}$ from the substrate by the rhizomes/roots of T. latifolia, as initial $\mathrm{Cu}$ rose and further decreased by 14th day exposure period. It showed that the substrate acts as a primary sink for the retention of $\mathrm{Fe}$ and $\mathrm{Cu}$ in the constructed microcosms. The results showed the need of proper and in-depth research on the fate of the metals (Fe and $\mathrm{Cu}$ ) in the substrates as an important parameter to assess the permanent and safe removal of the metals using constructed microcosm treatment techniques.

\section{Fe and $\mathrm{Cu}$ accumulation in T. Iatifolia}

The $\mathrm{Fe}$ and $\mathrm{Cu}$ accumulation in the T. latifolia biomass from the microcosms is presented in Fig. $3 a$ and $b$. The $\mathrm{Fe}$ accumulation increased from $348 \pm 41.23 \mathrm{mg} \mathrm{kg}^{-1}$ to $1446 \pm 36.01 \mathrm{mg} \mathrm{kg}^{-1}$ during $1 \mathrm{st}$ and 14th day of exposure in microcosm 1. The adsorption of Fe to the anionic sites, viz. phosphate and carboxyl groups in the cell walls, and the precipitation of $\mathrm{Fe}_{2} \mathrm{O}_{3}$ and $\mathrm{Fe}(\mathrm{OH})_{3}$ within the cell walls can be the reason for the rhizofiltration and its subsequent phytoaccumulation (Soltan and Rashed 2003). In addition,
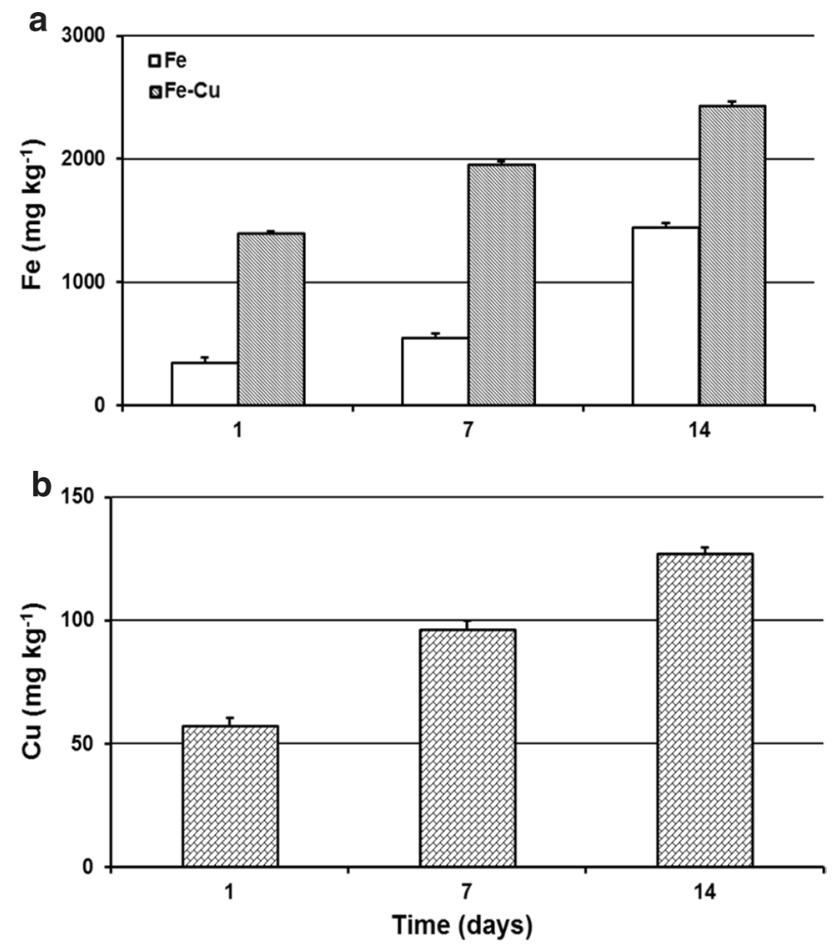

Fig. 3 Accumulation of (a) iron and (b) copper in T. latifolia of the two microcosms ( $\mathrm{Fe}$ and $\mathrm{Fe}-\mathrm{Cu})$. Error bars represent $\mathrm{SD}(n=3)$ some of the Fe-rich colloidals formed in the wastewater were absorbed by the underground rhizomatic tissues of T. latifolia possibly by solubilization and then subsequent assimilation through the secretion of organic acids outside the underground surface. The plants cultured in the microcosms 1 and 2 showed significant active effluxing of $\mathrm{Fe}$ and with time (7th to 14th day) probably to prevent any phytotoxic levels of $\mathrm{Fe}$ being accumulated in T. latifolia tissues. Likewise, root mediated precipitation $\left(\mathrm{Fe}\right.$ as $\mathrm{FePO}_{4}$ and $\mathrm{FeCO}_{3}$ ) and sedimentation of the $\mathrm{Fe}$ flocs were noticed during the stages of active effluxing to avoid $\mathrm{Fe}$ - phytotoxicity (Jayaweera et al. 2008). Most probably, Fe colloidals were formed inside the root cells and with a series of root exudates, involving some peptides for the flocculation of the colloidal particles. Anning et al. (2013) reported Fe, $\mathrm{Cu}$, $\mathrm{Zn}, \mathrm{Pb}$ and $\mathrm{Hg}$ accumulation up to 585.6, 28.4, 82.4, 5.6 and $5.14 \mathrm{mg} \mathrm{kg}^{-1}$, respectively, in the biomass of $T$. latifolia from constructed wetlands treating wastewater. In the presence of $\mathrm{Cu}$ in the microcosm 2, the accumulation of $\mathrm{Fe}$ increased up to $1390.36 \pm 23.56 \mathrm{mg} \mathrm{kg}^{-1}$ and $2425.65 \pm 41.01 \mathrm{mg} \mathrm{kg}^{-1}$ during 1st and 14th day of exposure period, respectively. Likewise, $\mathrm{Cu}$ concentration in T. latifolia increased from $57.15 \pm 3.4 \mathrm{mg} \mathrm{kg}^{-1}$ to $127.05 \pm 2.7 \mathrm{mg} \mathrm{kg}^{-1}$ during the exposure period of 1 st to 14 th day. La Fontaine et al. (2002) reported that the photosynthetic algae Chlamydomonas reinhardtii possesses both $\mathrm{Cu}$-dependent (orthologue to $\mathrm{Fet}_{3}$ ) and $\mathrm{Cu}$-independent pathways for $\mathrm{Fe}$ acquisition. However, it is indicated that $\mathrm{Fe}$ acquisition by roots does not require $\mathrm{Cu}$, but they instead depend on $\mathrm{Cu}$ independent transporters. Sancenon et al. (2003) reported that the plasma membrane $\mathrm{Cu}$ and $\mathrm{Fe}$ chelate reductase activities are inextricably linked. The root plasma membrane $\mathrm{Cu}$ and $\mathrm{Fe}$ reductase activities were significantly induced upon both $\mathrm{Cu}$ and $\mathrm{Fe}$ depletion in pea plants (Cohen et al. 1997). In addition, induction of ferric reductase activity by simultaneous $\mathrm{Fe}$ and $\mathrm{Cu}$ deficiency is synergetic rather than additive, which is consistent with a single gene responding to both $\mathrm{Fe}$ and $\mathrm{Cu}$ deficiency (Romera et al. 2003). Askwith et al. (1994) demonstrated in Saccharomyces cerevisiae that the connection between $\mathrm{Cu}$ and $\mathrm{Fe}$ homeostasis relies on the multicopper ferroxidase Fet3, responsible for yeast high affinity $\mathrm{Fe}$ uptake. Likewise, Wu et al. (2005) reported FRO2 (ferric reductase oxidase 2) and FRO3 (ferric reductase oxidase 2) as the main components responsible for $\mathrm{Fe}$ acquisition and metabolism in Arabidopsis roots. Ferric reductase oxidase 2-reductase also exhibits $\mathrm{Cu}$ reductase activity under Fe deficiency, and FRO3 expression increases in Arabidopsis roots upon both $\mathrm{Fe}$ and $\mathrm{Cu}$ limitation suggesting its involvement in $\mathrm{Fe}$ and $\mathrm{Cu}$ acquisition. However, there is a need of further detailed analysis on the mechanism of Fe uptake aggravation in the biomass of T. latifolia due to $\mathrm{Cu}$ supplementation. 

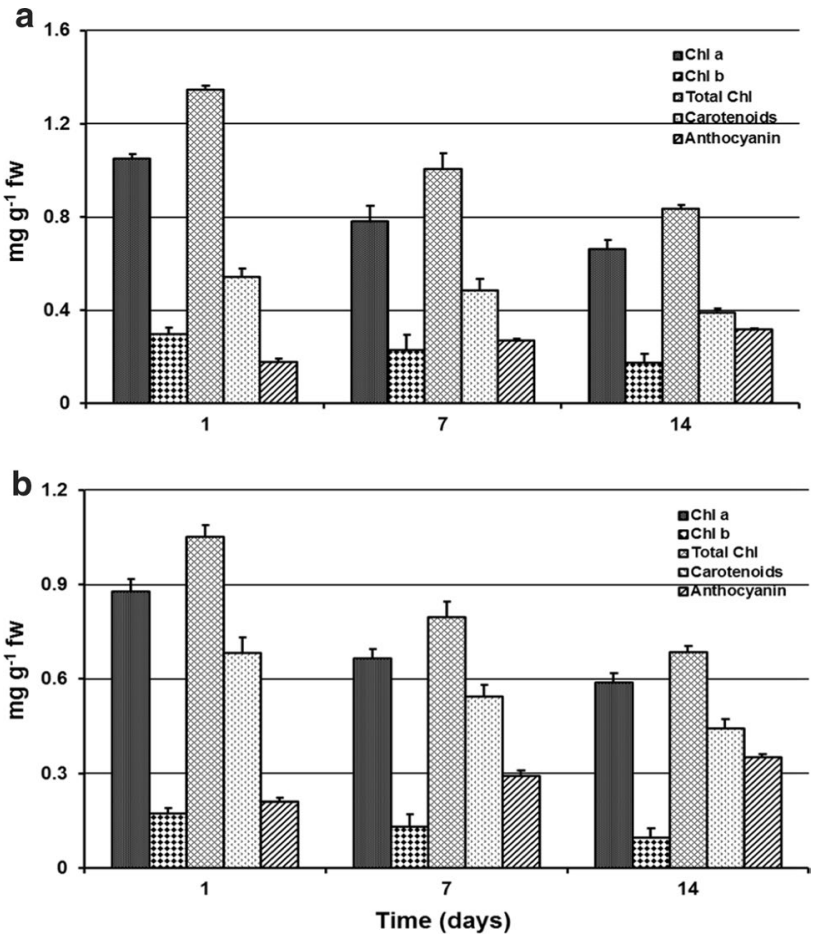

Fig. 4 Concentrations of photosynthetic pigments and anthocyanins in T. latifolia of the microcosms (a) $\mathrm{Fe}$ and (b) $\mathrm{Fe}-\mathrm{Cu}$. Error bars represent $\mathrm{SD}(n=3)$

\section{Photosynthetic pigment and anthocyanin content in T. Iatifolia}

Heavy metal stress inhibits the Chl biosynthetic pathways in many aquatic plants, destroys pigment, chloroplast membranes and thylakoid membranes leading to reduction in the photosynthetic efficiency (Meitei and Prasad 2014b). The reduction of $\mathrm{Chl}$ concentrations was observed in T. latifolia between 1st and 14th day of exposure period for both microcosms 1 and 2 (Fig. 4a and b). However, no sign of chlorosis was observed on the aboveground parts of T. latifolia exposed to 30 and $15 \mathrm{mg} \mathrm{L}^{-1}$ concentrations $\mathrm{Fe}$ and $\mathrm{Fe}-\mathrm{Cu}$ at the end of 14th day depicting the tolerant nature of T. latifolia. Moreover, carotenoids are reported to act as antioxidants against free radicals and photochemical damage, and the less reduction/change in the carotenoids level in the plants might represent its supportive role against oxidative stress (Sengar et al. 2008). During the study, anthocyanin concentration got increased in both the setups during the exposure period. It revealed that anthocyanin synthesis makes it an effective strategy against reactive oxygen species (ROS) generation during $\mathrm{Fe}$ and $\mathrm{Cu}$ stress. Anthocyanin not only scavenges free radicals but also binds the heavy metals or metal inducing ions in the vacuole and causes their detoxification in the cell (Krupa et al. 1996). Similar to our results, Manios et al. (2003) reported that T. latifolia showed no significant reduction in the pigment content when exposed to $\mathrm{Cd}, \mathrm{Cu}, \mathrm{Ni}, \mathrm{Pb}$ and $\mathrm{Zn}$, thereby concluding that no significant toxic action was imposed.

\section{Transfer coefficient of Fe in T. Iatifolia}

The concentration of Fe was $348 \pm 41.23 \mathrm{mg} \mathrm{kg}^{-1}$, attaining $1446 \pm 36.01 \mathrm{mg} \mathrm{kg}^{-1}$ during the exposure of 14th day, and corresponds to the maximum TC of $865.87 \pm 0.034 \mathrm{~L} \mathrm{~kg}^{-1}$ in microcosm 1 (Table 2). In the microcosm 2, when supplemented with $\mathrm{Cu}$, the $\mathrm{TC}$ of $\mathrm{Fe}$ increased from $1390.65 \pm 23.56 \mathrm{~L} \mathrm{~kg}^{-1}$ to $2425.65 \pm 41.01 \mathrm{~L} \mathrm{~kg}^{-1}$, respectively in 14th day. The high values of water-plant transfer coefficient explain the high uptake rate of Fe by T. latifolia in the microcosm constructed. It suggests the possible role of T. latifolia in the immobilization of $\mathrm{Fe}$ in natural aquatic environment by sequestering the metal in their tissues and thereby reducing the dispersion in the ecosystem. Similar to our findings, numerous reports have highlighted the potential of aquatic macrophytes for metal removal from various degraded environments using CW (Table 3). Batool (2020) reported that T. latifolia showed $95 \%, 91 \%$ and $89 \%$ removal efficiency of $\mathrm{Cu}, \mathrm{Zn}$ and $\mathrm{Pb}$ from synthetic leachate in constructed wetlands poly-cultured with $P$. australis. Likewise, a removal efficiency of $93.4 \%$ and $94 \%$ for $\mathrm{Cu}$ and $\mathrm{Zn}$ at the optimum contact time of $72 \mathrm{~h}$ was reported with $T$. latifolia and Cyperus papyrus in a constructed wetland treating agricultural wastewater (Hussien et al. 2020).

Table 2 Variation of Fe concentration in water and in plant and water-plant transfer coefficient as a function of exposure period (mean \pm standard deviation)

\begin{tabular}{|c|c|c|c|c|c|c|}
\hline \multirow{2}{*}{$\begin{array}{l}\text { Exposure } \\
\text { period }(\mathrm{h})\end{array}$} & \multicolumn{3}{|c|}{ Contaminated water with $\mathrm{Fe}$} & \multicolumn{3}{|c|}{ Contaminated water with $\mathrm{Fe}-\mathrm{Cu}$} \\
\hline & $\begin{array}{l}\text { Concentration of } \mathrm{Fe} \\
\left(\mathrm{mg} \mathrm{L}^{-1}\right) \text { in water }\end{array}$ & $\begin{array}{l}\text { Concentration of } \mathrm{Fe} \\
\left(\mathrm{mg} \mathrm{kg}^{-1}\right) \text { in plant }\end{array}$ & $\begin{array}{l}\text { Transfer coef- } \\
\text { ficient }\left(\mathrm{L} \mathrm{kg}^{-1}\right)\end{array}$ & $\begin{array}{l}\text { Concentration of } \mathrm{Fe} \\
\left(\mathrm{mg} \mathrm{L}^{-1}\right) \text { in water }\end{array}$ & $\begin{array}{l}\text { Concentration of } \\
\mathrm{Fe}\left(\mathrm{mg} \mathrm{L}^{-1}\right) \text { in } \\
\text { plant }\end{array}$ & Transfer coefficient $\left(\mathrm{L} \mathrm{kg}^{-1}\right)$ \\
\hline 24 & $26.87 \pm 0.043$ & $348.02 \pm 41.23$ & $12.95 \pm 0.013$ & $24.11 \pm 0.012$ & $1390.65 \pm 23.56$ & $57.67 \pm 0.032$ \\
\hline 168 & $4.68 \pm 0.054$ & $550.51 \pm 34.20$ & $117.62 \pm 0.011$ & $4.11 \pm 0.011$ & $1949.55 \pm 33.21$ & $474.34 \pm 0.018$ \\
\hline 336 & $1.67 \pm 0.076$ & $1446.18 \pm 36.01$ & $865.07 \pm 0.034$ & $0.87 \pm 0.013$ & $2425.65 \pm 41.01$ & $2788.10 \pm 0.027$ \\
\hline
\end{tabular}


Table 3 Performance of aquatic macrophytes for metal removal in different constructed wetlands

\begin{tabular}{|c|c|c|c|c|c|c|}
\hline S1. No & Type & Wastewater & Plants & Metals & Efficiency (\%) & References \\
\hline 1 & $\mathrm{Lab}$ & Synthetic & Canna indica & $\mathrm{Cu} \& \mathrm{Cr}$ & $87.2-99.5$ & Zhao et al. 2019 \\
\hline 2 & $\mathrm{Lab}$ & Agricultural & $\begin{array}{l}\text { Typha latifolia \& Cyperus } \\
\text { papyrus }\end{array}$ & $\mathrm{Cu} \& \mathrm{Zn}$ & $72-84$ & Hamad et al. 2020 \\
\hline 3 & Pilot & $\begin{array}{l}\text { Semi-synthetic storm- } \\
\text { water }\end{array}$ & $\begin{array}{l}\text { Canna indica \& Typha } \\
\text { latifolia }\end{array}$ & $\mathrm{Cd}, \mathrm{Cr}, \mathrm{Fe}, \mathrm{Pb}, \mathrm{Cu} \& \mathrm{Zn}$ & $70-98$ & Ventura et al. 2021 \\
\hline 4 & Full & Domestic & $\begin{array}{l}\text { Hydrocotyle ranuncu- } \\
\text { loides }\end{array}$ & $\mathrm{Zn}, \mathrm{Fe}, \mathrm{Cd}, \mathrm{Cu} \& \mathrm{~Pb}$ & $46-61$ & Custodio et al. 2020 \\
\hline 5 & $\mathrm{Lab}$ & Mine & $\begin{array}{l}\text { Scirpus grosus \& Eleo- } \\
\text { charis dulcis }\end{array}$ & $\mathrm{Fe}$ & $86.4-95.4$ & Sidek et al. 2020 \\
\hline 6 & $\mathrm{Lab}$ & Tannery & $\begin{array}{c}\text { Brachiaria mutica, Canna } \\
\text { indica, Cyperus laeviga- } \\
\text { tus, Leptochloa fusca \& } \\
\text { Typha domingensis }\end{array}$ & $\mathrm{Cr}$ & $23.1-55.2$ & Ashraf et al. 2020 \\
\hline 7 & $\mathrm{Lab}$ & Domestic & $\begin{array}{l}\text { Phragmites communis \& } \\
\text { Salix viminalis }\end{array}$ & $\begin{array}{l}\mathrm{Al}, \mathrm{Ba}, \mathrm{Mn}, \mathrm{Ni}, \mathrm{Sr}, \mathrm{V}, \mathrm{Zn}, \\
\mathrm{Cd}, \mathrm{Cu} \& \mathrm{~Pb}\end{array}$ & $58-91$ & $\begin{array}{l}\text { Samecka-Cymerman and } \\
\text { Kempers } 2004\end{array}$ \\
\hline 8 & $\mathrm{Lab}$ & Acid mine drainage & Juncus effusus & $\mathrm{Fe} \& \mathrm{Zn}$ & $69-97$ & Weissner et al. 2006 \\
\hline 9 & $\mathrm{Lab}$ & Municipal sewage & $\begin{array}{r}\text { Phragmites australis \& } \\
\text { Phalaris arundinacea }\end{array}$ & $\begin{array}{c}\mathrm{As}, \mathrm{Cd}, \mathrm{Co}, \mathrm{Cr}, \mathrm{Cu}, \mathrm{Fe}, \\
\mathrm{Mn}, \mathrm{Ni}, \mathrm{Pb}, \mathrm{Sn} \& \mathrm{Zn}\end{array}$ & $55.7-98.9$ & Vyzamal 2005 \\
\hline 10 & $\mathrm{Lab}$ & Tannery & Phragmites australis & $\mathrm{Cr}$ & 48 & Garcia-Valero et al. 2020 \\
\hline 11 & Pilot & Acid mine drainage & $\begin{array}{l}\text { Vetiveria zizanioides and } \\
\text { Phragmites australis }\end{array}$ & $\mathrm{Fe}, \mathrm{Zn}, \mathrm{Cu} \& \mathrm{Mn}$ & $14-40$ & Borralho et al. 2020 \\
\hline 12 & $\mathrm{Lab}$ & Synthetic & $\begin{array}{l}\text { Chenopodium album, } \\
\text { Amaranthus cruentus, } \\
\text { Phragmites australis \& } \\
\text { Bambusa vulgaris }\end{array}$ & $\mathrm{Cs} \& \mathrm{~Pb}$ & $67.5-98.4$ & Moogouei and Chen, 2020 \\
\hline 13 & Pilot & Industrial sewage sludge & $\begin{array}{l}\text { Eichhornia crassipes, Sal- } \\
\text { vinia molesta \& Pistia } \\
\text { stratiotes }\end{array}$ & $\begin{array}{l}\mathrm{Cd}, \mathrm{Cu}, \mathrm{Pb}, \mathrm{Ni}, \mathrm{Zn}, \mathrm{Fe} \\
\quad \& \mathrm{Cr}\end{array}$ & $26.6-58.6$ & $\begin{array}{l}\text { Kodituwakku and Yatawara } \\
2020\end{array}$ \\
\hline 14 & $\mathrm{Lab}$ & Agricultural & $\begin{array}{l}\text { Typha latifolia \& Cyperus } \\
\text { papyrus }\end{array}$ & $\mathrm{Cu} \& \mathrm{Zn}$ & $93.4-94$ & Hussien et al. 2020 \\
\hline 15 & $\mathrm{Lab}$ & Municipal & $\begin{array}{l}\text { Veronica anagallis-aquat- } \\
\text { ica, Mentha longi-folia, } \\
\text { Cyperus iria \& Nastur- } \\
\text { tium officinale }\end{array}$ & $\mathrm{Fe}, \mathrm{Pb}, \mathrm{Zn}, \mathrm{Cu}, \mathrm{Mn} \& \mathrm{Ni}$ & $53-61$ & Khalid and Ganjo 2020 \\
\hline 16 & $\mathrm{Lab}$ & Industrial & Phragmites australis & $\mathrm{Al}, \mathrm{Ba}, \mathrm{Cr}, \mathrm{Ga}, \mathrm{Ni}$ and $\mathrm{Zn}$ & $81-98$ & Gomes eta 1. 2019 \\
\hline 17 & Pilot & Municipal & $\begin{array}{l}\text { Phragmites australis \& } \\
\text { Typha latifolia }\end{array}$ & $\mathrm{Cu}, \mathrm{Zn} \& \mathrm{~Pb}$ & $89-95$ & Batool 2020 \\
\hline 18 & $\mathrm{Lab}$ & Saline & Canna indica & $\mathrm{Cu}, \mathrm{Zn}, \mathrm{Cd} \& \mathrm{~Pb}$ & $36.7-99$ & Liang et al. 2019 \\
\hline 19 & Pilot & Mining & Phragmites australis & As, $\mathrm{Mn}, \mathrm{Cd}, \mathrm{Zn} \& \mathrm{~Pb}$ & $38.7-96.9$ & Nguyen et al. 2019 \\
\hline 20 & $\mathrm{Lab}$ & Industrial & $\begin{array}{l}\text { Ludwigia abyssinica, } \\
\text { Hydrolea glabra \& Cer- } \\
\text { atophyllum demersum }\end{array}$ & $\mathrm{Pb}, \mathrm{Cr}, \mathrm{Mn} \& \mathrm{Zn}$ & $27.5-93.3$ & Johnson et al. 2019 \\
\hline 21 & Pilot & Domestic & Rhynchospora corymbosa & $\mathrm{Zn}, \mathrm{Al}, \mathrm{Mg} \& \mathrm{Fe}$ & $32.3-100$ & Raphael et al. 2019 \\
\hline 22 & Pilot & Industrial & $\begin{array}{c}\text { Phragmites australis, } \\
\text { Typha domingensis, } \\
\text { Leptochloa fusca \& } \\
\text { Brachiaria mutica }\end{array}$ & $\mathrm{Fe}, \mathrm{Cu}, \mathrm{Cr}, \mathrm{Ni}, \mathrm{Cd} \& \mathrm{~Pb}$ & 84.9-99.9 & Afzal et al. 2019 \\
\hline 23 & $\mathrm{Lab}$ & Industrial & Mentha aquatica & $\mathrm{Cd} \& \mathrm{~Pb}$ & $45.7-96.5$ & Dahija et al. 2019 \\
\hline
\end{tabular}

Thus, the results of our preliminary study in the laboratory microcosm conditions presented the tolerant nature and the phytofiltration potential of T. latifolia to strip Fe from the contaminated wastewater. However, the progress of the phytoremediation system needs to address a better understanding of the metal uptake mechanism, retention time in the plant tissues and its decomposition as plant litter in the sediment. The understanding of the basic interactions 
between plants, sediment, microorganisms and physical properties of water in the natural wetland system will help in designing long term remediation tactics built on natural models for remediation of various environments contaminated with numerous heavy metals (Prasad 2004). The techniques of phytoremediation using wetland plants thus represent an ecofriendly, aesthetically appealing, low-cost technique that can be useful for the cleanup of numerous environmental pollutants that are present in low to moderate levels (EPA 2001). Numerous studies have highlighted the potential of aquatic macrophytes to remove metals from different polluted environment (Meitei and Prasad 2016a, b; Johnson et al. 2019; Dahija et al. 2019; Ashraf et al. 2020; Borralho et al. 2020; Khalid and Ganjo 2020; Sidek et al. 2020). The aquatic vegetation of the wetlands via the process of phytoextraction sequesters the metals into their biomass and thus helps purify the contaminated environment. The aquatic plants in the wetlands also have high metal remediation potential because of their fast growth and high biomass production even in the highly contaminated environment, making them the best possible candidates for future remediation approach of metals. Today, the acquired information and knowledge can be applied in man-made systems that resemble the natural environment of the studied plant $(T$. latifolia) in the form of $\mathrm{CW}$ to protect numerous degraded ecosystems around the world.

\section{Conclusion}

As Fe pollution in various parts of the world poses a serious health and ecosystem threat, the concept of CW with Typha latifolia as an alternative sustainable treatment method for the removal of $\mathrm{Fe}$ from wastewater environment proved as a low-cost and eco-friendly approach. Further, the experiment showed that the removal efficiency of Fe increased with the supplementation of $\mathrm{Cu}$ in the microcosm, which showed the aggravating potential of $\mathrm{Cu}$ in $\mathrm{Fe}$ removal. Based on the results obtained, it can be concluded that the plant-based technology of CW using wetland plants needs to be properly exploited and researched for the restoration of ecosystems degraded with a number of heavy metals.

Acknowledgements The authors acknowledge University of Hyderabad for the facility provided.

Funding The author received no specific funding for this work.

\section{Compliance with ethical standards}

Conflict of interest The authors declare no conflict of interest.

Open Access This article is licensed under a Creative Commons Attribution 4.0 International License, which permits use, sharing, adaptation, distribution and reproduction in any medium or format, as long as you give appropriate credit to the original author(s) and the source, provide a link to the Creative Commons licence, and indicate if changes were made. The images or other third party material in this article are included in the article's Creative Commons licence, unless indicated otherwise in a credit line to the material. If material is not included in the article's Creative Commons licence and your intended use is not permitted by statutory regulation or exceeds the permitted use, you will need to obtain permission directly from the copyright holder. To view a copy of this licence, visit http://creativecommons .org/licenses/by/4.0/.

\section{References}

Anning AK, Korsah PE, Addo-Fordjour P (2013) Phytoremediation of wastewater with Limnocharis flava, Thalia geniculata and Typha latifolia in constructed wetlands. Inter J Phytorem 15(5):452-464

Afzal M, Rehman K, Shabir G, Tahseen R, Ijaz A, Hashmat AJ, Brix H (2019) Large-scale remediation of oil-contaminated water using floating treatment wetlands. npj Clean Water. 2; 3 .

Arnon DI (1949) Copper enzymes in isolated chloroplasts: polyphenol oxidases in Beta bulgaris. Plant Physiol 24:1-15

Ashraf S, Naveed M, Afzal M, Seleiman M, Al-Suhaibani NA, Zahir A, Mustafa A, Refay Y, Alhammad BA, Ashraf S, Alotaibi M, Abdella K (2020) Unveiling the potential of novel macrophytes for the treatment of tannery effluent in vertical flow pilot constructed wetlands. Water 12:549

Askwith C, Eide P, Van Ho A, Bernard PS, Li L, Davis-Kaplan S, Sipe DM, Kaplan J (1994) The FET3 gene of S. cerevisiae encodes a multicopper oxidase required for ferrous iron uptake. Cell $76: 403-410$

Batool A (2020) Metal accumulation from leachate by polyculture in crushed brick and steel slag using pilot-scale constructed wetland in the climate of Pakistan. Environ Sci Pollut Res 26:31508-31521

Bette A, Kutschera V (1996) Pigment accumulation and photosynthesis in developing rye coleoptiles. Bot Acta 109:194-198

Borralho T, Gago D, Almeida A (2020) Study on the application of floating beds of macrophytes (Vetiveria zizanioides and Phragmites australis), in pilot scale, for the removal of heavy metals from Água Forte stream (Alentejo-Portugal). J Ecol Eng 21(3):153-163

Cohen CK, Norvell WA, Kochain LV (1997) Induction of root cell plasma membrane ferric reductase. Plant Physiol 114:1061-1069

Custodio M, Orellana-Mendoza E, Peñaloza R, Cruz-Solano HD, Bulege-Gutiérrez W, Quispe-Mendoza R (2020) Heavy metal accumulation in sediment and removal efficiency in the stabilization ponds with the Hydrocotyle ranunculoides Filter. J Ecol Eng 21(5):72-79

Dahija S, Bešta-Gajević R, Jerković-Mujkić A, Đug S, Muratović E (2019) Utilization of Mentha aquatica L for removal of fecal pathogens and heavy metals from water of Bosna river, Bosnia and Herzegovina. Inter J Phytorem. 21(8):807-815

Duxbury AC, Yenstch CS (1956) Plankton pigment monograph. J Mar Res 15:93-101

EPA (2001) A Citizen's Guide to Phytoremediation. US Environmental Protection Agency, Office of Solid Waste and Emergency Response. EPA-542-F-01-002.

García-Valero A, Martínez-Martínez S, Faz Á, Terrero MA, Muñoz MÁ, Gómez-López MD, Acosta JA (2020) Treatment of wastewater from the tannery industry in a constructed wetland planted with Phragmites australis. Agronomy 10:176

Gomes MVT, Rodrigues de Souza R, Teles VS, Mendes EA (2014) Phytoremediation of water contaminated with mercury using 
Typha domingensis in constructed wetland. Chemosphere 103:228-233

Gomes HI, Mayes WM, Whitby P, Rogerson M (2019) Constructed wetlands for steel slag leachate management: Partitioning of arsenic, chromium and vanadium in waters, sediments and plants. J Environ Manag 243:30-38

Groudeva VI, Groudev SN, Doycheva SN (2001) Bioremediation of water contaminated with crude oil and toxic heavy metals. Inter J Min Process 62:293-299

Gurzau ES, Neagu C, Gurzau AC (2003) Essential metals - case study on Iron. Ecotoxicol Environ Safety 58(1):190-200

Hamad MTMH (2020) Comparative study on the performance of Typha latifolia and Cyperus papyrus on the removal of heavy metals and enteric bacteria from wastewater by surface constructed wetlands. Chemosphere 260:127551

Hussien MTM, El-Liethy MA, Abia ALK, Dakhil MA (2020) Lowcost technology for the purification of wastewater contaminated with pathogenic bacteria and heavy metals. Water Air Soil Pollut 231:400

Jayaweera MW, Kasturiarachchi JC, Kularatne RKA, Wijeyekoon SLJ (2008) Contribution of water hyacinth (Eichhornia crassipes (Mart.) Solms) grown under different nutrient conditions to Fe removal mechanisms in constructed wetlands. J Environ Manag $87: 450-460$

Johnson UE, Adeogun BK, Ugya AY (2019) Efficacy of aquatic plants in industrial effluent treatment using vertical subsurface flow constructed wetland; studies on Ceratophyllum demersum, Ludwigia abyssinica and Hydrolea glabra. Inter J Eng 17(1):213-217

Joint FAO/WHO Expert Committee on Food Additives (1983) Toxicological evaluation of certain food additives and food contaminants. Cambridge University Press

Khalid KM, Ganjo DGA (2020) Native aquatic plants for phytoremediation of metals in outdoor experiments: implications of metal accumulation mechanisms, Soran City-Erbil, Iraq. Inter J Phytorem. https://doi.org/10.1080/15226514.2020.1815645

Kodituwakku KARK, Yatawara M (2020) Phytoremediation of industrial sewage sludge with Eichhornia crassipes, Salvinia molesta and Pistia stratiotes in batch fed free water flow constructed wetlands. Bull Environ Cont Toxicol 104:627-633

Krupa Z, Baranowska M, Orzol P (1996) Can anthocyanin be considered as a heavy metal stress indicator in higher plants? Acta Physiol Plant 18:147-151

La Fontaine S, Quinn JM, Nakamoto SS, Page MD, Gohre V, Moseley JL, Kropat J, Merchant S (2002) Copper dependent iron assimilation pathway in the model $\mathrm{f}$ photosynthetic eukaryote Chlamydomonas reinhardtii. Euk Cell 1:736-757

Lange H, Shropshire W, Mohr H (1971) An analysis of phytochrome mediated anthocyanin synthesis. Plant Physiol 47:649-655

Liang Y, Zhu H, Bañuelos G, Xu Y, Yan B, Cheng X (2019) Preliminary study on the dynamics of heavy metals in saline wastewater treated in constructed wetland mesocosms or microcosms filled with porous slag. Environ Sci Pollut Res 26:33804-33815

Manios T, Stentiford EI, Millner PA (2003) The effect of heavy metals accumulation on the chlorophyll concentration of Typha latifolia plants, growing in a substrate containing sewage sludge compost and watered with metaliferus water. Ecol Eng 20(1):65-74

Meitei MD, Prasad MNV (2013) Lead (II) and cadmium (II) biosorption on Spirodela polyrhiza (L) Schleiden biomass. J Environ Chem Eng. 1(3):200-207

Meitei MD, Prasad MNV (2014) Adsorption of Cu (II), Mn (II) and Zn (II) by Spirodela polyrhiza (L.) Schleiden: Equilibrium, kinetic and thermodynamic studies. Ecol Eng 71:308-317

Meitei MD, Prasad MNV (2016a) Metal bioavailability in phoomdicompost from Loktak lake (Ramsar site), Manipur, north-east India. In: Trace elements in temporary waterlogged soils and sediments. CRC press - Taylor \& Francis group. pp. 341-351.
Meitei MD, Prasad MNV (2016b) Bioaccumulation of nutrients and metals in sediments, water and phoomdi from Loktak lake (Ramsar site), northeast India; phytoremediation options and risk assessment. Environ Monitor Assess 188:329

Meitei MD, Kumar A, Prasad MNV, Malec P, Waloszek A, Maleva G, Strzalka K (2014) Photosynthetic pigments and pigment-protein complexes of aquatic plants under heavy metal stress. In: Photosynthetic pigments: chemical structure, biological function and ecology. Omi Scientific Centre of the Ural Branch of the Russian Academy of Sciences, Syktyvkar, pp 319-334

Metcalf EI, Tchobanoglous G, Burton FL (2003) Wastewater engineering - treatment and reuse, 4th edn. McGraw Hill Companies Inc., New york, USA

Moogouei R, Chen Y (2020) Removal of cesium, lead, nitrate and sodium from wastewater using hydroponic constructed wetland. Inter J Environ Sci Technol 17:3495-3502

Nguyen HTH, Nguyen BQ, Duong TT, Bui ATK, Nguyen HTA, Cao HT, Mai NT, Nguyen KM, Pham TT, Kim KW (2019) Pilot-scale removal of arsenic and heavy metals from mining wastewater using adsorption combined with constructed wetland. Minerals 9:379

Noller BN, Woods PH, Ross BJ (1994) Case studies of wetland filtration of mine wastewater in constructed and naturally occurring systems in northern Australia. Water Sc Technol 29:257-266

O'Sullivan AD, Moran BM, Otte ML (2004) Accumulation and fate of contaminants $(\mathrm{Zn}, \mathrm{Pb}, \mathrm{Fe}$ and $\mathrm{S})$ in substrates of wetlands constructed for treating mine wastewater. Water Air Soil Pollut 157:345-364

Prasad MNV (2004) Phytoremediation of metals and radionuclides in the environment; the case for natural hyperaccumulators, metal transporters, soil amending chelators and transgenic plants. In: Heavy metal stress in plants. Springer, Berlin, Heidelberg, pp 345-391

Raphael OD, Ojo SIA, Ogedengbe K, Eghobamien C, Morakinyo AO (2019) Comparison of the performance of horizontal and vertical flow constructed wetland planted with Rhynchospora corymbosa. Inter J Phytorem 21(2):152-159

Romera FJ, Frejo VM, Alcantara E (2003) Simultaneous Fe and Cu deficiency synergically accelerates the induction of several $\mathrm{Fe}$ deficiency stress responses in strategy 1 plants. Plant Physiol Biochem 41:821-827

Samecka-Cymerman A, Stepien D, Kempers AJ (2004) Efficiency in removing pollutants by constructed wetland purification systems in Poland. J Toxicol Environ Health A 67:265-275

Sancenon V, Puig S, Mira H, Thiele DJ, Pennarubia L (2003) Identification of a copper transporter family in Arabidopsis thaliana. Plant Molecul Biol 51:577-587

Sengar RK, Gautam M, Sengar RK, Grag SK, Sengar K, Chaudhary R (2008) Lead stress effects on physiobiological activities of higher plants. Rev Environ Cont Toxicol 196:73-93

Sidek NM, Ahmad NU, Abdullah SRS, Draman SFS (2020) Phytoremediation of ex mining lake water in constructed wetland by perennial plants. J Nat Sci 19(3):580-594

Soltan MS, Rashed MN (2003) Laboratory study on the survival of water hyacinth under several conditions of heavy metal concentrations. Advances Environ Res 7:321-334

Tel-Or E, Forni C (2011) Phytoremediation of hazardous toxic metals and organics by photosynthetic aquatic systems. Plant Biosyst 145(1):224-235

Ventura D, Ferrante M, Copat C, Grasso A, Milani M, Sacco A, Licciardello F, Cirelli GL (2021) Metal removal processes in a pilot hybrid constructed wetland for the treatment of semi-synthetic stormwater. Sc Tot Environ 754:142221

Vyzamal J (1995) Algae and element cycling in wetlands. Lewis publishers. CRC Press, Boca Raton, Florida USA

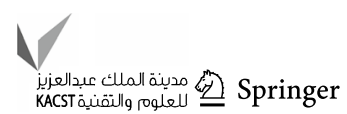


Vyzamal J (2005) Removal of heavy metals in a horizontal sub-surface flow constructed wetland. J Environ Sci Health 40:1369-1379

Wiessner A, Kuschk P, Buddhawong S, Stottmeister U, Mattusch J, Kästner M (2006) Effectiveness of various small-Scale constructed wetland designs for the removal of Iron and Zinc from acid mine drainage under field conditions. Eng Life Sci 6(6):584-592

World Health Organisation (2011) Guidelines for drinking water quality, 4th edn. WHO, Geneva

Wu H, Li L, Du J, Yuan Y, Cheng X, Ling HQ (2005) Molecular and biochemical characterization of the Fe (II) chelate reductase gene family in Arabidopsis thaliana. Plant Cell Physiol 46:1505-1514

Wu S, Vyzamal J, Brix H (2019) Critical review: Biogeochemical networking of iron in constructed wetlands for wastewater treatment. Environ Sci Technol 53:7930-7944
Zhao Z, Xu C, Zhang X, Song X (2019) Addition of iron materials for improving the removal efficiencies of multiple contaminants from wastewater with a low $\mathrm{C} / \mathrm{N}$ ratio in constructed wetlands at low temperatures. Environ Sci Pollut Res 26:11988-11997

Publisher's note Springer Nature remains neutral with regard to jurisdictional claims in published maps and institutional affiliations. 